consulting him regularly throughout the Second World War. During this period he was awarded the Ph.D. of the University of Edinburgh for his work on bomb ballistics.

At the outbreak of the Second World War, Cunningham was appointed by the Director of Scientific Research, Air Ministry, to lead a small body of research workers in the development and application of a mathematical theory of air combat which he had earlier produced. The scope of the work of this group, called the Air Warfare Analysis Section, and its strength, expanded rapidly during the War until it eventually covered a very wide field, ranging from the geodetic work associated with the blind-bombing tactics of the R.A.F. to the statistical theory of aimwander in aerial gunnery.

In 1945 Cunningham was elected a fellow of the Royal Society of Edinburgh. Security restrictions unfortunately prevented the publication of much of his work, but a joint paper with W. R. B. Hynd on the application of the theory of random processes to air-warfare, read recently before the Royal Statistical Society, indicates the trend of much of his recent work.

Cunningham was prevented by his death from taking up a high appointment at the Royal Aircraft Establishment, Farnborough, and his loss will be keenly felt throughout the sphere of air armaments. $\mathrm{He}$ will be remembered with affection by all who worked with him.

E. C. CORnFord

WE regret to announce the following deaths :

Sir Carsuthers Beattie, during 1918-37 vicechancellor and principal of the University of Cape Town, on September 10, aged seventy-nine.

Sir James Jeans, O.M., F.R.S., on September 16, rged sixty-nine.

Nikolai Morozov, honorary member of the Academy of Sciences of the U.S.S.R., known for his general writings on scientific topics, on July 13, aged ninetytwo.

\section{$81=$ \\ Engineering at Edinburgh: Prof. R. N. Arnold}

Prof. R. N. Arnold has been appointed to the regius chair of engineering in the University of Edinburgh. Hol. Arnold completed a brilliant studentshif robrd by graduating at the University of Gasow 1932 with first-class honours, and followed th A drectly with a period on research, which qualified $h\left(f_{f} f_{r}\right.$ the associateship of the Royal Technical College and won the principal College research award. Appointment to a Senior Caird Scholarship then followed, and with this, he went to Sheffield to continue his work on engineering materials in Prof. Lea's laboratory. This phase of his research career was notable for work on embrittlement, the theme of several important papers and the subject of his thesis for the Ph.D. degree. In 1934 he accepted appointment to a Commonwealth Fund Fellowship and spent the two succeeding years at the University of Illinois. His work there was marked by a significant change from the more static type of materials investigation to the dynamical questions of impact and vibration; and his later publications have demonstrated his interest and power in this field.

On his return from Illinois in 1936, Dr. Arnold was appointed to a lectureship in the Department of Civil and Mechanical Engineering in the Royal Technical College, Glasgow, where in addition to a wide range of teaching, he took a prominent part in the special investigations conducted by the department. His work on the topical engineering problem of the 'singing propeller' was particularly valuable, and the papers published by him and his colleagues on this subject aroused considerable attention and gained the Gold Medal of the Institute of Engineers and Shipbuilders in Scotland and the Thomas Lowe Gray Prize of the Institution of Mechanical Engineers. In 1941, Dr. Arnold joined the senior staff of the Metropolitan-Vickers Electrical Co., and while there was engaged on many important investigations. Later pepers on some of these have made him widely known as a main authority on such diverse lines as machine tool dynamometry and gyroscopie stabilization problems. The latter was the subject of his thesis for the Glasgow D.Sc., which gave a fine

\section{nd VIEW S}

demonstration of analytical and experimental powers, adequately and successfully combined with inventive faculty and design capacity. He was appointed professor of engineering at University College, Swansea, in 1944, and leaves this position to succeed the late Sir Thomas Hudson-Beare at Edinburgh. Scottish engineering will welcome his return. He brings a fine teaching experience and real gifts of exposition to the instruction of its students, and a proved and polished research power to aid its development.

\section{Geology at University College, London : Prof. S. E. Hollingworth}

Dr. S. E. Holc agworth has been appointed to the Yates-Goldsmidv chair of geology in University College, Lredo hron leaving Cambridge, Dr. Hollingworth foires he Geological Survey in 1921 and went to the Cumbrian unit then based on Whitehaven. $\mathrm{He}$ took part in the survey of the Whitehaven, Gosforth, Cockermouth and Brampton sheets. In Whitehaven and Gosforth he was concerned mainly with Borrowdale rocks and with the Ennerdale Granophyre, but had some Carboniferous rocks with hæmatite. In the Cockermouth Sheet he was allotted the area including the Carrock Fell Complex, made classic by Harker, the greisen mass (with tungsten deposits) of the Skiddaw Granite and the metamorphic aureole of Skiddaw Slates, the Eycott and the northern area of Borrowdales with the Caldbeck mining field, mainly derelict but including the barytes deposit of Potts Ghyll. Much of this work is as yet unpublished, but marks an advance on that of previous workers. In the Brampton area he was concerned mainly with Lower Carboniferous strata and Triassic rocks with gypsum. Here he became particularly interested in drift deposits which led to his paper on glaciation in Western Edenside (Quart. J. Geol. Soc., p. 281, 1931), which was accepted for D.Sc. London. On the dispersal of the Cumbrian unit, Dr. Hollingworth was sent to the Droitwich area, mainly on Trias, and later to that around Cambridge, with its widespread Drift and Recent deposits. At the outbreak of war it was essential that assistance from the Survey should be forthcoming on home ore deposits, 